\title{
COMMUNICATIVE MECHANISMS IN THE SYSTEM OF POLITICAL RESPONSIBILITY OF MODERN SOCIETY
}

\section{Dunayeva L. M.}

\section{INTRODUCTION}

In today's world, the problems of becoming an information society are becoming more and more relevant. The significant challenge is that the social basis of political power is gradually being transformed and mediated through mass communication processes. In these circumstances, the study of the phenomenon of political responsibility becomes especially relevant, especially in the transitional periods of society, which are usually accompanied by a crisis of trust between the public and the authorities, the need to find mechanisms to increase the effectiveness of the process of political decisionmaking and implementation, ensuring sustainable development.

Political responsibility is one of the public institutions that are transformed by the influence of communication processes. This is due to the changing fundamentals of political interaction between public authorities and civil society institutions. In today's world, people's behavior is increasingly influenced by information messages that determine the political agenda.

On the other hand, societies seeking to exercise power in a democratic way face the problem of rationally restricting the individual's democratic freedoms for the benefit of the public good. Awareness of the growing need for political participation of individuals in the democratic process leads to the mythologization and hyperbolization of the degree of their participation in the process of socially significant decisions of the information age, enhances the political responsibility of the institutions of civil society, of every citizen.

The issue of political responsibility is linked to a wide range of issues that are relevant to all spheres of public life and aspects of socio-political interaction, one of which is the communicative dimension. Its solution requires exploring the communicative mechanisms of political responsibility and their transformations in the context of democratic transformations of government and society.

The purpose of the article is to identify the communicative mechanisms of political responsibility and their transformation in the context of democratic transformations of government and society. To achieve this goal it is necessary to solve the following research problems:

- to explore the evolution of scientific approaches to understanding the idea of political responsibility and the stages of its formation in the history of political thought; 
- to determine theoretical and methodological foundations of the study of political responsibility;

- to investigate the political responsibility of the authorities of the modern and postmodern era;

- to consider communicative factors influencing the level of political responsibility;

- to explore the basic principles of accountability of democratic power;

- to analyze the process of institutionalization of political responsibility in Ukraine.

\section{The evolution of scientific approaches to understanding the idea of political responsibility}

At different historical stages of society development, the phenomenon of responsibility was explained from the standpoint of mythological ideas, religious outlook, ideological doctrines, and scientific paradigms. In the history of scientific thought different ways of substantiating the idea of responsibility are distinguished, among them the theological concept of responsibility, social, moral, political, professional concept of responsibility.

In archaic societies, responsibility was explained in the language of myth, and its basis was the transcendental will of the gods, the elements, the primary sources. In Greek thought, the problem of responsibility is interpreted in the context of philosophical knowledge.

In the Roman Empire, the emphasis was placed on the legal component of political and civil responsibility (Cicero, Seneca, etc.). At the stage of the Middle Ages, the theological doctrine of responsibility was substantiated by P. Abeliar, Avhustyn Blazhennyi, Toma Akvinskyi, Marsylii Paduan-skyi, Helasii, V. Okkam and others, who insisted that the responsibility of man to God does not depend on origin, power, and social position.

During the Renaissance, the problem of responsibility returned to the earthly dimension - responsibility for one's own success, the state, and the subjects. One of the theorists of this understanding of responsibility was $\mathrm{N}$. Machiavelli, who substantiated the proposition that politics does not need the support and approval of morality or religion. In the period of modern times (XVII - XVIII centuries) the problem of relations between the individual and the state was solved in the theories of "natural rights" and "social contract". These theories were developed by T. Hobbs, Huho Hrotsii, D. Didro, T. Dzhefferson, I. Kant, D. Lokk, T. Pein, Zh. - Zh. Russo, B. Spinoza and others. These concepts combine political responsibility and legal (constitutional) responsibility.

Further interpretations of the phenomenon of responsibility in the history of political thought are linked to the development of these approaches, as well as the theories of elites (H. Moska, V. Pareto, R. Mikhels), political power and bureaucracy (M. Veber), and political culture (H. Almond, S. Verba). 
Since the Renaissance, the concept of responsibility has been linked to moral doctrines. The level of political responsibility was directly dependent on the moral principles professed by politicians and citizens, and the ability to take responsibility indicated the level of moral development of the individual. In the moral doctrine of political responsibility, the principles, values and norms that were formed in the process of political activity were conceptualized, summarized and reflected in the form of ethical theories.

During the modern and postmodern days, the problem of governmental responsibility holded a special place. In the process of modernization, political responsibility was linked to the whole system of policy making and implementation. This implied certain consequences for certain actions of the authorities: political (election loss, so-called "retrospective responsibility") and legal (defined by law, in particular - constitutional responsibility).

The mechanisms of exercising the responsibility of the modern-day authorities include the dissolution of parliaments, impeachment, the recall of individual parliamentarians, election procedures, legal norms, resignation of governments, freedom of speech in the media, the right to criticize the authorities.

In the second half of the twentieth century, in the process of deconstruction of logocentrism, power and law, politics and science, a reinterpretation and concept of political responsibility took place. Postmodernization implied a transition from the industrial model of the state "labor - state capital" to the postmodern model "consumer - state - producer", which meant shifting responsibility from vertically organized and hierarchical structures to horizontal interaction.

\section{2. "Theoretical and methodological foundations of the study of political responsibility"}

The classification of types of responsibility depends on the sphere of social activity, in connection with which political, moral, social, legal, professional responsibilities are distinguished.

The political analysis of interpretations of political responsibility presupposes its implementation in different and interrelated dimensions: responsibility of public authorities and, above all, of the state before citizens; responsibility of different branches of government; responsibility of political parties to citizens; political responsibility of citizens. The main approaches to the consideration of political responsibility are constitutional-legal, political and social-moral approaches.

Ukrainian scientist Tarasenko T.M. summarizing the political responsibility existing in the special political science literature, writes that the common characteristics of political responsibility, which are presented in contemporary publications, include the determination that this responsibility: 
- for the purposeful use of power (political representation);

- fulfillment or non-fulfillment of the proclaimed programs, obligations, promises;

- whether or not the promises made by political figures (entities) are consistent to their real activity, social protection of the population, damage caused to society through improper activity, development of society, realization of citizens' rights;

- the responsibility of the political opposition for the harm caused to society through inappropriate activities;

- election of representatives of public authorities by citizens at elections;

- the correspondence between the real problems in society and their awareness of the reforming politicians;

- the inability of public authorities and officials to develop and implement policies aimed at the progressive development of society;

- the misappropriation of statutory functions and powers by policy entities;

- political, economic and social consequences for citizens of decisions and actions of public authorities;

- actions or decisions that have had adverse effects on the community, individual groups or individuals;

- improper exercise of the power given by some or other persons to the people as the sole source of power ${ }^{1}$.

Political responsibility stems from the peculiarities of political relations and the rules that govern them. The peculiarity of political responsibility lies in the fact that its essence is a negative assessment of the political misconduct of the actor by the public.

In legal science, specific responsibility is allocated - constitutional (or constitutional-legal), a significant contribution to the research of which has been made by Ukrainian scientists Pohorilko V.F., Todyka Yu.M., Frytskyi O.F., Shapoval V.M. and others.

At the present stage of political development, the basis of the process of political responsibility formation is the full functioning of democratic political institutions, the election of officials in free elections, the rule of law, equal access to the media, and the autonomy of public organizations. The work of such foreign authors as H. Almond, S. Verba, L. Daimond, D. Darendorf, R. Dal, A. Leipkhart, D. Rastou, Dzh. Sartori, O. Soloviov, Y. Shumpeter and

${ }^{1}$ Tarasenko M. Poniattia politychnoi vidpovidalnosti $\mathrm{v}$ konteksti naukovykh doslidzhen iz mistsevoho samovriaduvannia/ Teoriia ta praktyka derzhavnoho upravlinnia/ Kharkivskyi rehionalnyi instytut derzhavnoho upravlinnia NADU pry Prezydentovi Ukrainy. \# 3 (58)/2017. - S. 3. 
others. Among the Ukrainian researchers are the works of B. Andresiuk, Ye. Bystrytskoho, V. Horbatenko, A. Kolodii, V. Kremen, M. Orzikh, F. Rudycha, S. Riabov, Yu. Shemchushenko, D. Yakovlev and others.

These authors have developed such theories of responsibility as communicative theory of responsibility, technocratic theory of responsibility, socio-psychological theory of responsibility, regulatory theory of responsibility, normative theory of responsibility, theory of individual responsibility, functional theory of responsibility and legal theory of responsibility. Among these are political theories in which responsibility is divided into retrospective and prospective.

In the course of the evolution of a democratic political system and a rule of law, an understanding of political responsibility as a communicative phenomenon is formed. The communicative component of the process of political responsibility formation is constructed in the course of interaction between government and society (vertical interaction), between authorities (constitutional and legal responsibility) and civil society institutions (horizontal interaction). The basis of political responsibility for this understanding is not only the activities of the authorities, but also the relations between the informed citizens and the authorities. In this theory, the emphasis is on the fact that in today's context these relations are mediated by the information space, in particular - by the activities of the media, which have played an extremely important role in the electoral process in virtually all countries of the world, regardless of the particularities of their political regime.

At the present stage, communicative mechanisms of political responsibility formation play a decisive role. This is driven by the development of information technology, the mediation of the political process, and the growing influence of Internet communications on political reality. In the process of forming communicative mechanisms of political responsibility, democratic norms of state responsibility are inferior to the principles of the autonomy of the administrative sphere, and instead of the traditionally inherent to the civil service management principle, the partnership model is approved.

Political responsibility in communicative interaction between government and society is manifested in individual and collective forms. Society has a large arsenal of means that can be used as sanctions against power actors: nonviolent protest methods, civil disobedience, lustration, restriction on political rights, and finally, the so-called "political death" of the actor. Such sanctions can be applied to both authorities and opposition politicians.

In today's context, political activity begins with the process of interpretation of information, and the space of political interaction is the information message of the media, which in some way influence the formation of public opinion, structure and rules of political game. These processes also 
fully relate to the phenomenon of political responsibility. The communicative dimension of political responsibility lies in the general, agreed definition of the essence of the relationship between political actors and society, which is influenced by the activities of the media and accepted by the majority of participants in the course of communication.

Modern-day communication, mediated by technological innovation, is transforming the institution of political responsibility and creating new challenges for democracy. For the specific area of political interaction between government and citizens, which is a political responsibility, factors such as changing the system of representation of civic interests in accordance with the requirements of the media format and creating new forms of communication in the sphere of public authority are important. At the same time, globalization creates new challenges for government accountability, such as the need for subsidiarity, changes in the functions and scope of responsibility ("boundaries" of responsibility) of the nation-state, the emergence of new global political actors (TNCs, international nongovernmental organizations, supranational authorities, etc.).

\section{Communicative factors influencing the political level responsibility in democratization}

The evolution and current state of political responsibility formation in modern Ukrainian society is largely determined by the Soviet heritage, the tradition of power-society interaction. From the point of view of "MarxismLeninism" political responsibility was considered as a component of the constitutional guarantee of popular sovereignty. Thus, the adoption of the Constitution of the USSR of the Brezhnev era was considered "a new stage in the unfolding of socialist democracy and the responsibility of the Soviet people for the future." In this case, people's sovereignty was defined as the supremacy and authority of the people, and the concept of "people's sovereignty", "democracy", "democracy" as inseparable from socialism.

The Soviet system was characterized by the extreme degree of categorization, monopolization and centralization of all spheres of public life, which led to the creation of a space of irresponsibility in relations between citizens and the authorities, and formed an appropriate political culture, which is inadequate for the system of political democracy.

In today's transitional society, political responsibility is characterized by particular characteristics. In the process of democratization of society and government, the responsibility of politicians and citizens is manifested primarily in the course of election campaigns, and the phenomenon of "decisive elections" is emerging. The responsibility of politicians during this period is retrospective, and is the ability of civil society to remove from power in the election political parties and forces that do not carry out their election 
programs. This is exactly what happened during the 2019 presidential and parliamentary elections. The results of these elections were a clear demonstration of the political responsibility of former government officials, the head of state, parliamentary coalition, political elites and leaders for political decision-making and implementation, political responsibility of the media and civil society institutions. Real political accountability of political actors is not possible without a developed civil society.

There is a crisis of responsibility, which is manifested most in the moral and professional plane, and is in the absence of adequate value guidelines for the needs of modern social development, the lack of democratic traditions of the dialogue between the authorities and society, the willingness to listen to the moral authorities (like V. Havel, A. Sakharov).

The notion of responsibility in the system of public power depends on the specific functions and powers of the government, parliament, president, local authorities, etc. The general trend is that the role of government is increasing, especially in parliamentary and semi-presidential republics. In parliamentary countries, the formation of a government is carried out by a party or coalition of parties that form a parliamentary majority. Presidential form of government is characterized by the fact that the President heads the government, actively uses its right of legislative initiative, issues its own acts that contribute to strengthening the position of the government in the system of higher authorities. The political responsibility of the government has such a specialty as collegiality.

Political responsibility comes in the form of political and politicallegal sanctions applied to political subjects: negative public assessment in political elections, public mistrust, initiation of the procedure of applying political-legal sanctions according to law, resignation, or deprivation of authority of the subject politicians, refusal to register for the elections, cancellation of state registration of a political party.

Features of political responsibility in modern society are to reduce the role of ideologies, the transformation of political parties into «voting machines», the destruction of communication between the cells of parties and local communities, the dominance in the political space of indirect forms of political communication, the mediation of politics, insufficient development of political parties and effectiveness of civil society institutions, imperfection of legal procedures for implementation of the principle of responsibility.

Among the factors influencing the level of political responsibility should be identified such components as moral and constitutional law. Political responsibility is exercised in the sphere of political activity, and its level is connected with the type of political regime, political activity of citizens, activity of independent mass media, political consciousness and culture, etc. Political responsibility combines two forms: the response of 
society to the actions of politicians and the response of political actors to the demands of society. Therefore, responsibility in the modern world is a special communicative type of interaction between society and government. In modern conditions, the necessary factors of political responsibility formation are the responsibility of the media, the treatment of information as an important public resource, not as a commodity, and the independence of the mass media from public authorities. There is an urgent need to establish ongoing links, communication channels between public authorities and civil society institutions in order to enhance political accountability. This applies not only to vertical communications (state - society), but also to horizontal communications between different social groups. In the first and the second case, the activity of the mass media, whose task is to provide timely and qualitative information to the stakeholders, is extremely important. Thus, the scope of political participation of citizens in politics expands, and accordingly - the mechanism of political responsibility changes. The communicative interaction of modern times, mediated by technological innovations, is transforming the institution of political responsibility and creating new challenges for democracy.

\section{4. "Institutionalization of Political Responsibility in Ukraine"}

The main directions of forming an institution of political responsibility at the present stage of political development of Ukrainian society are to improve the legal mechanisms for ensuring accountability and to increase the role of civil society in the implementation of the principles of political responsibility.

The radical changes of recent decades that have taken place in the world require a revision of the content of political responsibility and the legal mechanisms for securing it. In modern Ukrainian society, there is a process of institutionalization of qualitatively new legal institutions (e.g. NACBU, NAPC) aimed at overcoming the phenomenon of corruption, which has become widespread in the sphere of Ukrainian politics. These institutions should significantly strengthen the mechanisms of constitutional liability and, above all, in the field of politics.

Constitutional responsibility is a system-forming element of the system of protection of constitutional rights and relations. The Constitution defines the basic rights and duties of the authorities and citizens, the balance of power, the division of areas of responsibility between the center and the regions, the executive, legislative and judicial branches of state power.

The main institutional subject of political responsibility is the state, as it is the main subject of public authority in society. The state bears political responsibility to citizens whose community acts as a civil society in relation to the state. The political responsibility of the state to civil society is realized as 
the responsibility of the elected higher bodies of state power, which are the parliament and the president. Elections and referendums are the main institutional means of realizing such a responsibility in today's democratic society ${ }^{2}$.

Political responsibility becomes a determining factor in the modernization type of political development. For the creation of mechanisms of political and legal accountability in post-communist Ukraine, the draft Law «On Political Responsibility» (registered in the Verkhovna Rada of Ukraine on April 9, 2010 by People's Deputy M. Papiiev), which, unfortunately, was subsequently withdrawn from registration was important. The further political practice of Ukrainian society is increasingly providing arguments for the need to adopt a law on constitutional liability, which would become a significant deterrent to the irresponsible activities of public authorities and politicians.

Regarding the system of organization of state power, the factors of its irresponsibility include centralization of power, remoteness of the center of decision-making from local communities, underdeveloped local selfgovernment, lack of authority to solve local problems, low efficiency of decision-making and implementation of political decisions, lack of transparency of government, closedness the mechanism of decision-making and implementation of power decisions, the nomination of the functioning of certain political institutions and the mechanisms that should provide articulation of interests and political responsibility, conservation and restoration of undemocratic inherently political institutions and practices.

Improving the effectiveness of political relations, their qualitatively new meaningful content is possible in the presence of developed institutions of civil society, which perform the function of controlling the activities of the authorities. Self-organization of citizens, their ability to act together and involvement of civil society in the political process are at the forefront.

In the process of democratic transition, one of the important factors is the responsibility of civil society. It is becoming increasingly clear that the hindrances to the realization of the tasks of civil society in the implementation of democratic principles of political responsibility are the main factors: paternalism formed by years of totalitarian and subsequently authoritarian domination, economic factors related to the complexity of market reforms, political ideology and political ideology, major community groups, etc.

It is impossible to develop political responsibility without a developed civil society, which performs the functions not only of controlling the actions of the public by the public, but also of formulating rational alternatives for social development, dialogue with the authorities, protecting the interests of citizens' associations. In the process of forming political responsibility, one of the main problems is the correlation of social and state foundations

${ }^{2}$ Malkina H. Demokratiia i politychna vidpovidalnist. Suchasna ukrainska polityka. Polityky i politolohy pro nei. K., 2010. Vyp. 21 (36). S. 26. 
(interaction between civil society and government), social and political regulators (public associations and political parties).

A special aspect of political responsibility is the role of the nationbuilding people, their awareness of their history and future. The Ukrainian scientist V. Toryanik rightly draws attention to this problem, who writes: «The people as a whole are not criminals, just as they are not immoral, but the collective political responsibility cannot be removed from the people, it is always on them and there's nowhere to hide from it. This responsibility lies in the fact that each of the individuals forming the nation experiences the consequences of the actions of the politicians and citizens of the state under whose authority it is and under the order of which it is. Everyone is jointly and severally responsible for the way they are governed» ${ }^{3}$.

Political responsibility is also measured in the subjective forms of human activity in the political sphere. It is pointed out by researcher R. Zhmudsky, who notes that the subjectivity of political responsibility in public administration is also manifested in the fact that such factors as the level of political and legal culture of the population (including the proper level of knowledge about the content of government policy, local authorities and self-government), the development of political institutions and structures of civil society, the ability of citizens to consciously, rationally evaluate the activities of governmental structures, trust in state institutions, and expectation of fair and careful consideration by the representatives of the authorities of the issues addressed to them by citizens ${ }^{4}$.

Political responsibility is a system of political interactions between the people as a bearer of sovereign power, civil society and public authority, which is intended to express the will of the people through state sovereignty. The level of political consciousness, political culture, system of common civilizational, basic values, a qualitative system of communication mechanisms should define and direct the form and content of relations between the authorities and the people, their responsibility for the future of the country. In the system of this interaction between public authority and civil society, communication mechanisms play an increasingly important role, in the structure of which the media play a dominant role and, at the same time; acquire the status of an extremely important factor in the political accountability mechanism of modern democratic society.

${ }^{3}$ Torianik V. Vzaiemna politychna vidpovidalnist derzhavnoi vlady i hromadia-nyna v suchasnii pravovii derzhavi: Avtoref. dys. kand. polit. nauk: 23.00.02. Dnipropetrovsk, 2006. S.17.

4 Zhmudskyi R. Politychna vidpovidalnist u derzhavnomu upravlinni/ Zbirnyk naukovykh prats Natsionalnoi akademii derzhavnoho upravlinnia pry Prezydentovi Ukrainy. 2011. S. 205-206. 


\section{SUMMARY}

The evolution and tendencies of development of communicative mechanisms of political responsibility are considered in the article, its peculiarities and specific features are analyzed.

It is determined that communicative mechanisms of political responsibility are formed in the process of interaction between the authorities and the society, between the authorities and the institutions of civil society. It is substantiated that in modern conditions political interaction is mediated by the development of information technologies, the mediation of the political process and the growing influence of Internet communications on political reality.

The place of political responsibility in the process of democratic development is analyzed. It is determined that political responsibility becomes a determining factor in the modernization type of political development. The level of responsibility is determined both by the activities of governmental institutions and by the development of civil society, the availability of independent media, regular and free elections.

\section{REFERENCES}

1. Zhmudskyi R. Politychna vidpovidalnist u derzhavnomu upravlinni..Zbirnyk naukovykh prats Natsionalnoi akademii derzhavnoho upravlinnia pry Prezydentovi Ukrainy. 2011. S. 198-207. URL: www.irbis-nbuv.gov.ua/cgi-bin/irbis_nbuv.

2. Malkina H. M. Demokratiia i politychna vidpovidalnist. Suchasna ukrainska polityka. Polityky i politolohy pro nei. K., 2010. Vyp. 21(36). S. 23-32.

3. Tarasenko M. Poniattia politychnoi vidpovidalnosti $\mathrm{v}$ konteksti naukovykh doslidzhen iz mistsevoho samovriaduvannia. Teoriia ta praktyka derzhavnoho upravlinnia. Kharkivskyi rehionalnyi instytut derzhavnoho upravlinnia NADU pry Prezydentovi Ukrainy. № 3 (58)/2017. S. 1-8.

4. Torianik V. Vzaiemna politychna vidpovidalnist derzhavnoi vlady i hromadianyna v suchasnii pravovii derzhavi: Avtoref. dys. kand. polit. nauk: 23.00.02. Dnipropetrovsk, 2006. 20 s.

Information about the author: Dunayeva L. M., Doctor of Political Science, Professor, Odesa National I. I. Mechnikov University 2, Dvorianska str., Odessa, 65082, Ukraine 